DEMOGRAPHIC RESEARCH

VOLUME 40, ARTICLE 5, PAGES 95-120

PUBLISHED 22 JANUARY 2019

https://www.demographic-research.org/Volumes/Vol40/5/

DOI: 10.4054/DemRes.2019.40.5

Research Article

The weight of school entry: Weight gain among Hispanic children of immigrants during the early elementary school years

Michelle L. Frisco

Erin Baumgartner Jennifer Van Hook

(C) 2019 Michelle L. Frisco, Erin Baumgartner \& Jennifer Van Hook.

This open-access work is published under the terms of the Creative Commons Attribution 3.0 Germany (CC BY 3.0 DE), which permits use, reproduction, and distribution in any medium, provided the original author(s) and source are given credit.

See https://creativecommons.org/licenses/by/3.0/de/legalcode. 


\section{Contents}

1 Introduction $\quad 96$

$\begin{array}{lll}2 & \text { Background } & 98\end{array}$

3 Data and methods $\quad 100$

$\begin{array}{lll}3.1 & \text { Measures } & 102\end{array}$

3.2 Methods 103

$4 \quad$ Results $\quad 105$

5 Discussion 111

$\begin{array}{ll}\text { References } & 114\end{array}$ 


\title{
The weight of school entry: Weight gain among Hispanic children of immigrants during the early elementary school years
}

\author{
Michelle L. Frisco ${ }^{1}$ \\ Erin Baumgartner ${ }^{2}$ \\ Jennifer Van Hook ${ }^{3}$
}

\begin{abstract}
BACKGROUND

Hispanic children of immigrants are vulnerable to obesity and weigh more than their white peers. Theory suggests that school is a social institution that could foster weight gain among Hispanic children of immigrants and disparities in weight that emerge over time.
\end{abstract}

\section{OBJECTIVE}

We investigate whether Hispanic children of immigrants gain more weight during school years than whites and whether school year weight gains accumulate and contribute to differences in the weight of Hispanic children of immigrants and whites.

\section{METHODS}

We analyze ECLS-K:2011 kindergarten, first, and second grade data using descriptive statistics and multilevel growth curve models. We also calculate how the accumulation of weight gain during school years and summer breaks contributes to weight disparities between Hispanic children of immigrants and whites by the end of second grade.

\section{RESULTS}

Hispanic children of immigrants gain significantly more weight than white and Hispanic children with US-born parents during the kindergarten school year. The accumulation of weight gain during kindergarten, first, and second grade school years contributes to weight disparities between Hispanic children of immigrants and whites, but not differences between Hispanic and white children with US-born parents.

\footnotetext{
${ }^{1}$ Pennsylvania State University, University Park, PA, USA. Email: mlfrisco@gmail.com.

${ }^{2}$ Rice University, Houston, USA.

${ }^{3}$ Pennsylvania State University, University Park, PA, USA.
} 


\section{CONCLUSION}

Hispanic children of immigrants are vulnerable to weight gain during kindergarten. In addition, weight gain during the earliest school years helps to explain emerging ethnic/parental nativity disparities in weight.

\section{CONTRIBUTION}

The paper extends knowledge about negative health assimilation among Hispanic children of immigrants by showing that a primary social institution in children's lives may inadvertently contribute to weight gain and emerging disparities in weight.

\section{Introduction}

Currently, one in four children in the United States is Hispanic, and the majority of these children have at least one parent who is an immigrant (Fry and Passel 2009). It has been well documented for many health outcomes that life in the United States takes a toll on the health of immigrants and their children. For example, even though Mexican-born children of immigrants have very low obesity prevalence prior to migration, they gain weight quickly following migration to the United States (Van Hook et al. 2012). These children, and Hispanic children of immigrants more generally, are more vulnerable to obesity and weight gain than their peers with US-born parents (Balistreri and Van Hook 2009; Van Hook, Baker, and Altman 2009). This is worrisome considering that childhood obesity is related to several chronic health conditions (Dietz 1998) and reduced life expectancy (Masters, Powers, and Link 2013; Preston, Vierboom, and Stokes 2018). This raises important questions about how the US environment contributes to weight gain and obesity among Hispanic children of immigrants.

A number of studies have explored family, neighborhood, and child-level factors associated with obesity or obesity-related outcomes among children of immigrants, such as parents' socioeconomic status (Balistreri and Van Hook 2009), living in a neighborhood with other co-ethnics (Kimbro and Denney 2013; Van Hook et al. 2016), children's acculturation (Gordon-Larsen et al. 2003), and gender (Frisco, Quiros, and Van Hook 2016; Van Hook and Baker 2010). However, the role that schools may have in facilitating weight gain among young children of immigrants remains relatively unexplored.

We expect that Hispanic children of immigrants are more vulnerable to weight gain during the school year than peers with US-born parents, a supposition derived from theory about health assimilation and the role that formal US social institutions have in the assimilation of immigrants and their families (Alba and Nee 2003; Gordon 
1964). School is a US social institution with formal and informal structures that foster general acculturation (Alba and Nee 2003) and dietary acculturation (Dondero et al. 2018). Aspects of the acculturation process in school, such as learning US peer culture and English language acquisition, are stressful (Berry 2006) and heightened stress facilitates weight gain (Drapeau et al. 2003). Hispanic children of immigrants also eat more Americanized foods and less traditional Mexican foods while at school (Dondero et al. 2018), and dietary acculturation is positively associated with body mass index (BMI) (Akresh 2007).

We estimate whether Hispanic children of immigrants' average monthly weight gain during the school year is higher than white children with US-born parents, the largest group of children in US elementary schools who are also leaner than Hispanic children (Ogden et al. 2018). We also compare the weight gain patterns of Hispanic and white children with US-born parents to ensure that any findings observed for children of immigrants are unique to them and not representative of all Hispanic children. This is key for assessing the strength of the arguments that we make about school as a social institution that fosters acculturation.

We have two research expectations. We anticipate that Hispanic children of immigrants' average monthly weight gain during the school year will be higher than US-born peers. Additionally, we expect to find that differences in school year monthly weight gain between Hispanic children of immigrants and whites significantly contribute to disparities in weight that emerge between these two groups by the end of second grade.

We evaluate these research expectations by analyzing data from the Early Childhood Longitudinal Study of the Kindergarten Class of 2010-2011 (ECLS$\mathrm{K}: 2011)$, which includes measured assessments of body weight and height during the fall and spring of the kindergarten, first grade, and second grade school years. ${ }^{4}$ This enables us to follow a similar approach used in previous studies to disentangle weight gain during school years and summer breaks (Von Hippel et al. 2007; Von Hippel and Workman 2016). Our focus on kindergarten, first grade, and second grade is a particularly salient time for examining weight gain among children because these grades are school years aligned with the adiposity rebound, or the time when BMI begins rising after infancy, which generally occurs between ages 2 and 7 (Cole 2004).

\footnotetext{
${ }^{4}$ After second grade, the ECLS-K:2011 stopped collecting data at two yearly time points and began collecting data only during the spring of each school year. As a result, it is not possible to estimate school year weight gains in grades three and beyond.
} 


\section{Background}

Theory regarding negative health assimilation argues that across time in the United States and generations, immigrant health declines due to exposure to the US environment (Antecol and Bedard 2006; Hamilton et al. 2011). Support for negative health assimilation is dependent upon the health outcome studied, but there is evidence for this process when investigating health behaviors such as obesity (Antecol and Bedard 2006; Popkin and Udry 1998) and diet (Akresh 2007).

Drawing upon new assimilation theory (Alba and Nee 2003), we theorize that elementary school may operate as a formal US social institution that inadvertently contributes to negative health assimilation due to formal and informal institutional structures that facilitate weight gain among Hispanic children of immigrants. To be clear, we do not argue that schools deliberately foster weight gain or negative health assimilation. Instead, it is the stress, pressure to assimilate, and changes in diet that Hispanic children of immigrants face as a result of a school's formal and informal structure that lead us to expect these children to gain more weight during the school year than peers with US-born parents.

Our argument is based on Alba and Nee's (2003) theory about the ways that US social institutions such as the government, religious institutions, and schools foster assimilation. These social institutions have a bureaucratic structure in place that facilitates standardization and they formally and informally regulate the behavior of individuals who interact with them. Thus, there are formal and informal expectations for behavior that reinforce US norms and reward conformity to norms through social approval from superiors and peers, meaning that immigrants and their family members can achieve a sense of group membership by assimilating and conforming to US norms.

Elementary school is the primary formal institution that introduces Hispanic children of immigrants to US social, behavioral, and cultural norms (Alba and Nee 2003; Pong and Hao 2007). While all children face new social realities when they begin school (Eccles 1999), this transition is especially salient for children in immigrant households because the formal structure of school and the way that schools bring children of immigrants together with classmates with US-born parents brings pressure to conform to US school and peer group norms (Alba and Nee 2003). For example, all children navigate formal school rules, behavioral norms, and teacher and staff assessments (Apple and King 1977; Bordieu 1977; Laureau 2011), but children of immigrants do so in a context where they are less ready for school than US-born peers (Magnuson, Lahaie, and Waldfolgel 2006; Turney and Kao 2009), more likely to come from non-English speaking households, and more likely to be English language learners (Capps et al. 2005). All children also navigate new peer norms, but children of immigrants do so with less knowledge of US customs and behaviors (Rumbaut 2005; 
Suárez-Orozco and Suárez-Orozco 2009), including those related to eating and physical activity.

As a result, Hispanic children of immigrants enter elementary school with more pressures to adapt to the formal and informal structure of school than US-born peers, which is stressful (Berry 2006). Their identity formation process is also ripe with conflict and stress (Rumbaut 1994) and they are likely to experience discrimination by teachers and peers (Rosenbloom and Way 2004), which is also stressful. Stress is one of several reasons why we posit that Hispanic children of immigrants may gain more weight than white children with US-born parents during the school year. ${ }^{5}$ Stress contributes to weight gain by setting off a series of physiological processes that affect fat storage and accumulation (Drapeau et al. 2003).

Weight gain among Hispanic children of immigrants may also be higher than USborn peers during the school year because schools' formal institutional structures and school peer culture foster dietary assimilation. The National School Lunch Program provides limited funding for school meals (USDA 2017), which leads schools to purchase frozen meals from large-scale national distributors to minimize costs, maximize efficiency, and provide food that appeals to students. The result is highly standardized cafeteria menus that foster dietary assimilation (Poppendick 2010; Weaver-Hightower 2011). School food service offerings also change eating behaviors among children of immigrants more broadly, leading them to desire and eat more Americanized, less healthy food than their parents (McArthur, Viramontez Anguiano, and Nocetti 2001; Salazar 2007).

Peer culture in school also produces pressure for dietary assimilation (Salazar 2007). This may explain why prior quantitative (Dondero and Van Hook 2016) and qualitative (McArthur, Anguiano, and Nocetti 2001; Sussner, Lindsay, and Peterson 2009) research finds that children in immigrant households eat different and more Americanized food than their mothers, particularly when they are at school (Dondero et al. 2018). While dietary assimilation is not perfectly correlated with unhealthy eating (Dondero et al. 2018), pressure to eat more Americanized food fosters unhealthy eating and overeating in experimental research (Gundelman, Cheryan, and Monin 2011).

In sum, we expect higher monthly school year weight gains among Hispanic children of immigrants relative to peers with US-born parents because the formal and informal institutional structure of elementary school fosters general and dietary assimilation that produces stress and more Americanized, less healthy, and excess eating. This is particularly likely during kindergarten when Hispanic children of immigrants are newcomers to the institution, but it is possible that continued general

\footnotetext{
${ }^{5}$ We acknowledge that all Hispanic children in the United States are more likely to face discrimination that causes stress, which points to the importance of comparing Hispanic children of immigrants to both white and Hispanic children with US-born parents.
} 
and dietary assimilation in later grades also leads to higher monthly weight gains in first and second grade (and possibly beyond ECLS-K grade-levels analyzed in our study).

We also expect that group differences in the accumulation of school year monthly weight gains will lead Hispanic children of immigrants to be heavier than white children by the end of second grade, the last school year included in our analysis. All children's monthly weight gain is greater in the summer than during the school year, but these school versus summer weight gain differences while significant, are quite small, and all children gain weight during both the summer and school year (Von Hippel et al. 2007; Von Hippel and Workman 2016). The academic year is also longer (on average, 9.35 months per year) than summer break (about 2.65 months). Thus, even small significant differences in the average monthly school year weight gains of Hispanic children of immigrants relative to whites can accumulate over one or several school years to produce group differences in weight. We test this notion by estimating how children's weight at school entry; average monthly weight gain during the kindergarten, first grade, and second grade school years; and weight gain during summer breaks contribute to differences in the weight of Hispanic children of immigrants and white children by the end of second grade. We produce analogous estimates to compare Hispanic and white children with US-born parents to ensure that any findings about Hispanic children of immigrants are unique to them and not all Hispanic children.

\section{Data and methods}

We analyze data from the restricted-use ECLS-K:2011, a nationally representative US sample of approximately 18,000 children who attended public or private kindergarten during the 2010-2011 academic year. The ECLS-K:2011 longitudinally assesses children's elementary school educational and developmental trajectories. More detailed information about the dataset is available at the ECLS-K:2011 website (National Center for Education Statistics 2018).

Our sample consists of approximately $6,500^{6}$ kindergarteners who participated in six waves of data collection during fall and spring of kindergarten, first grade, and second grade. These children are white or Hispanic children with US-born parents or Hispanic children of immigrants. At each wave, children's height and weight were measured. Thus, we analyze 39,000 weight records nested within 6,500 children attending one of 850 elementary schools. The measurements of weight and height in

\footnotetext{
${ }^{6}$ All Ns are rounded to the nearest 10 per NCES data guidelines on reporting findings from the restricted-use ECLS-K:2011.
} 
both fall and spring are critical for calculation of average monthly weight gains during each school year and summer.

We excluded roughly $10 \%$ of white and Hispanic ECLS-K:2011 children who were enrolled in summer school and year-round schools. The demographic characteristics of excluded summer school students, which comprise the majority of dropped cases, were not significantly different than the characteristics of students who did not attend summer school. The characteristics of the 200 excluded students attending year-round schools suggest that they are slightly more disadvantaged than students attending schools with 'traditional' school years. The proportion of Hispanic children of immigrants attending year-around schools is also slightly higher than the proportion attending schools with traditional school years, but so few students attend year-around schools that this is unlikely to influence study findings.

Because several variables in the analysis had substantial missing data (e.g., approximately $36 \%$ of the study sample had missing data on parents' income and $33.2 \%$ had missing data on maternal education), we impute missing data on all analytic variables. This includes the dependent variable, consistent with recommendations by Young and Johnson (2018) and Johnson and Young (2011). We use SAS and the callable program IVEware, which iteratively replaces missing values on variables with predictions based on random draws from the posterior distributions of parameters observed in the sample, creating multiple complete data sets. We average empirical results across ten imputations and account for random variation across samples to calculate standard errors using Rubin's (1987) rules.

We conducted sensitivity tests to assess whether missing data biased study results. We estimated statistical models using data from the sample observed after listwise deletion of missing data. Results from these models were similar to results we show, but the latter estimates are slightly more conservative and better represent the ECLS$\mathrm{K}: 2011$ sample. We also estimated supplementary models that omitted respondents with imputed values for the dependent variable, BMI, because our modelling strategy does not require complete outcome data at each time point. Results from these models were similar to those using imputed BMI values. Finally, we estimated a model that omitted students who were not included in the subsample of ECLS-K:2011 students assessed during the first grade fall wave of data collection. Although this subsample is nationally representative, it is unclear whether these cases are entirely missing at random, which is an assumption for multiply imputing missing data. Results from these analyses were also similar to those presented here. Overall, results from these three sets of sensitivity tests show the robustness of study findings. 


\subsection{Measures}

We assess weight and weight gain using children's BMI calculated from measured assessments of height and weight from six time points: fall and spring of kindergarten, first grade, and second grade. We also estimated models where weight was operationalized using age-and-sex specific BMI percentiles and BMI z-scores. Results from these models produced findings that were substantively similar to those produced when estimating BMI, but results using BMI are slightly more conservative. We show models estimating BMI because it is a better measure for estimating change in weight than BMI percentiles and z-scores (Berkey and Colditz 2007; Cole et al. 2005). That said, we include BMI z-scores that show ethnic/parental nativity differences in baseline weight and weight at the end of second grade in Table 2 for readers who are curious about disparities in an indicator of adiposity that is age and sex adjusted.

We classify children into three ethnic/parental nativity groups: Hispanic children of immigrants (those with at least one foreign-born parent), Hispanic children of natives (those with two US-born parents), or non-Hispanic white children of US-born parents (reference). In supplementary analyses we defined Hispanic children of immigrants using maternal nativity only. Results were substantively and statistically similar to results shown here, which is not surprising because maternal and paternal nativity are highly correlated (.80).

Children's exposure to the school years and summers is a time-varying variable, estimating the cumulative number of months of exposure to kindergarten, first grade, second grade, and the summers in between grades at the time of each wave. It is based on reported dates of the beginning and end of the school year and dates when children's height and weight were measured.

Multivariate multilevel models include several control variables. They include parent reports of children's birth weight (in ounces) and indicators of children's sociodemographic background: gender $(1=$ male), family structure (living with both parents (reference), a single parent, a stepparent, or with another guardian during fall of kindergarten), age (in months) at kindergarten entry, mother's education level (did not complete high school, completed high school (reference) or completed at least some college $^{7}$ ), and family income, an ordinal categorical variable ranging from 1 ( $\$ 5000$ or less) to 18 ( $\$ 200,001$ or more). As Table 1 shows, the average family income of the study sample is 8.39 , which translates into roughly $\$ 35,600$. This average masks the much higher income of white children relative to Hispanic peers. We also control for the primary language spoken at home $(1=$ not English $)$, receipt of free or reduced-price school lunch during kindergarten, center-based care/pre-kindergarten attendance in the

\footnotetext{
7 "At least some college" is our highest education category because so few mothers of immigrants in the ECLS-K:2011 attained college degree.
} 
year before kindergarten, and whether children attended part-day or full-day $(=1)$ kindergarten.

\subsection{Methods}

We present weighted descriptive statistics for the total sample and by ethnicity/parental nativity in Table 1. We then show weighted bivariate associations between ethnicity/parental nativity and BMI and BMI z-scores at the beginning of kindergarten and the end of second grade in Table 2.

Next, we estimate a series of weighted multivariate multilevel growth curve models to assess whether weight gain during kindergarten, first grade, and second grade is significantly higher for Hispanic children of immigrants relative to white and Hispanic children with US-born parents. To estimate these models, we organized data into child-assessment records, with each child contributing one record for each of the six weight assessments. Multilevel models treat each BMI assessment (Level 1) as nested within children (Level 2), who are nested within schools (Level 3). The Level 1 model predicts child $\mathrm{i}$ in school s's BMI at time $t$ as a function of his/her cumulative exposure (measured in months, as of the time of the assessment) to kindergarten $\left(A_{t i}\right)$, first grade $\left(\mathrm{B}_{\mathrm{ti}}\right)$, and second grade $\left(\mathrm{C}_{\mathrm{ti}}\right)$, and the summers following kindergarten $\left(\mathrm{D}_{\mathrm{ti}}\right)$ and first grade $\left(\mathrm{E}_{\mathrm{ti}}\right)$ :

$$
\mathrm{BMI}_{\text {tis }}=\beta_{0 \text { is }}+\beta_{1 \text { is }} \mathrm{A}_{\text {tis }}+\beta_{2 \text { is }} \mathrm{B}_{\text {tis }}+\beta_{3 \text { is }} \mathrm{C}_{\text {tis }}+\beta_{4 \text { is }} \mathrm{D}_{\text {tis }}+\beta_{5 \text { is }} \mathrm{E}_{\text {tis }}+\varepsilon_{\text {tis }}
$$

The Level-2 and Level-3 equations fit the Level-1 intercept as a function of ethnicity/parental nativity, Hispanic children of immigrants $\left(\mathrm{COI}_{\mathrm{i}}\right)$ and Hispanic children of natives $\left(\mathrm{CON}_{\mathrm{i}}\right)$ at the child level $\mathrm{i}$, and a random effect $\left(\delta_{\mathrm{s}}\right)$ at the school level s:

$$
\beta_{0 \text { is }}=\gamma_{0}+\gamma_{1} \mathrm{COI}_{\mathrm{is}}+\gamma_{2} \mathrm{CON}_{\mathrm{is}}+\delta_{\mathrm{s}}+\theta_{\mathrm{is}} .
$$

The combined model is:

$$
\begin{aligned}
\mathrm{BMI}_{\text {tis }}= & \gamma_{0}+\gamma_{1} \mathrm{COI}_{\text {is }}+\gamma_{2} \mathrm{CON}_{\text {is }}+\beta_{1 \text { is }} \mathrm{A}_{\text {tis }}+\beta_{2 \mathrm{is}} \mathrm{B}_{\text {tis }}+\beta_{3 \text { is }} \mathrm{C}_{\text {tis }}+\beta_{4 \text { is }} \mathrm{D}_{\text {tis }}+ \\
& \beta_{5 \text { is }} \mathrm{E}_{\text {tis }}+\delta_{\mathrm{s}}+\theta_{\text {is }}+\varepsilon_{\text {tis. }}
\end{aligned}
$$

The intercept, $\gamma_{0}$, estimates BMI at the beginning of kindergarten, and the remaining coefficients, $\beta_{\text {1is }}$ through $\beta_{5 \text { is }}$, estimate average monthly weight gain during each respective school year and summer break. This equation represents Model 1 in this 
analysis. Model 2 adds a vector of control variables $\left(\mathrm{X}_{\text {is }}\right)$ to Model 1 . Model 3 adds interactions between ethnicity/parental nativity and the exposure variables to assess whether weight gain in kindergarten, first, and second grade and the summers between grade levels varies by ethnicity/parental nativity:

$$
\begin{aligned}
\mathrm{BMI}_{\text {tis }}= & \gamma_{0}+\beta_{1 \text { is }} \mathrm{A}_{\text {tis }}+\beta_{2 \text { is }} \mathrm{B}_{\text {tis }}+\beta_{3 \text { is }} \mathrm{C}_{\text {tis }}+\beta_{4 \mathrm{is}} \mathrm{D}_{\text {tis }}+\beta_{5 \mathrm{is}} \mathrm{E}_{\text {tis }}+\gamma_{1} \mathrm{COI}_{\text {is }}+\gamma_{2} \mathrm{CON}_{\text {is }}+\gamma_{3} \mathrm{X}_{\text {is }}+ \\
& \gamma_{4} \mathrm{COI}_{\text {is }} \mathrm{A}_{\text {tis }}+\gamma_{5} \mathrm{COI}_{\text {is }} \mathrm{B}_{\text {tis }}+\gamma_{6} \mathrm{COI}_{\text {is }} \mathrm{C}_{\text {tis }}+\gamma_{7} \mathrm{COI}_{\text {is }} \mathrm{D}_{\text {tis }}+\gamma_{8} \mathrm{COI}_{\text {is }} \mathrm{E}_{\text {tis }}+ \\
& \gamma_{9} \mathrm{CON}_{\text {is }} \mathrm{A}_{\text {tis }}+\gamma_{10} \mathrm{CON}_{\text {is }} \mathrm{B}_{\text {tis }}+\gamma_{11} \mathrm{CON}_{\text {is }} C_{\text {tis }}+\gamma_{12} \mathrm{CON}_{\text {is }} D_{\text {tis }}+ \\
& \gamma_{13} \mathrm{CON}_{\text {is }} \mathrm{E}_{\text {tis }}+\delta_{\mathrm{s}}+\theta_{\text {is }}+\varepsilon_{\text {tis }} .
\end{aligned}
$$

Our final analysis uses the coefficients from Model 3 to calculate whether the accumulation of time that children are exposed to school contributes to Hispanic children of immigrants weighing more than white children with US-born parents by the end of second grade. The predicted BMI by the end of second grade for each group (with average characteristics for all control variables) is a combination of weight at the beginning of kindergarten; monthly weight gain during kindergarten, first grade, and second grade multiplied by the duration of time in school (approximately 9.35 months); and monthly weight gain over the two summers multiplied by the duration of summer breaks (approximately 2.65 months).

White children with US-born parents:

$$
\gamma_{0}+9.35\left(\beta_{1 \mathrm{i}}+\beta_{2 \mathrm{i}}+\beta_{3 \mathrm{i}}\right)+2.65\left(\beta_{4 \mathrm{i}}+\beta_{5 \mathrm{i}}\right)+\gamma_{3} \bar{X}_{i}
$$

Hispanic children of immigrants:

$$
\gamma_{0}+\gamma_{1}+9.35\left(\beta_{1 \mathrm{i}}+\beta_{2 \mathrm{i}}+\beta_{3 \mathrm{i}}+\gamma_{4}+\gamma_{5}+\gamma_{6}\right)+2.65\left(\beta_{4 \mathrm{i}}+\beta_{5 \mathrm{i}}+\gamma_{7}+\gamma_{8}\right)+\gamma_{3} \bar{X}_{i}
$$

Hispanic children with US-born parents:

$$
\gamma_{0}+\gamma_{2}+9.35\left(\beta_{1 \mathrm{i}}+\beta_{2 \mathrm{i}}+\beta_{3 \mathrm{i}}+\gamma_{9}+\gamma_{10}+\gamma_{11}\right)+2.65\left(\beta_{4 \mathrm{i}}+\beta_{5 \mathrm{i}}+\gamma_{12}+\gamma_{13}\right)+\gamma_{3} \bar{X}_{i}
$$

For example, white children's BMI at the end of second grade is the sum of their weight at the beginning of kindergarten for children with average characteristics $\left(\gamma_{0}+\gamma_{3}\right.$ $\left.\bar{X}_{i}\right), 9.35$ times their monthly weight gain during kindergarten $\left(\beta_{1 i}\right)$, first grade $\left(\beta_{2 \mathrm{i}}\right)$, and second grade $\left(\beta_{3 i}\right)$, and 2.65 times their monthly weight gain during the summer between kindergarten and first grade $\left(\beta_{4 \mathrm{i}}\right)$ and between first and second grade $\left(\beta_{5 \mathrm{i}}\right)$. 
As we note in the background section of the manuscript, we compare both Hispanic children of immigrants and Hispanic children with US-born parents to white children with US-born parents. Based on equations 1-3, we estimated the predicted differences from non-Hispanic white children as:

Hispanic children of immigrants:

$$
\gamma_{1}+9.35\left(\gamma_{4}+\gamma_{5}+\gamma_{6}\right)+2.65\left(\gamma_{7}+\gamma_{8}\right)
$$

Hispanic children with US-born parents:

$$
\gamma_{2}+9.35\left(\gamma_{9}+\gamma_{10}+\gamma_{11}\right)+2.65\left(\gamma_{12}+\gamma_{13}\right) .
$$

\section{Results}

Table 1 describes the total sample and ethnic/parental nativity subsamples. Consistent with national data, more Hispanic children have immigrant parents than US-born parents. One in five children in the sample is a Hispanic child of an immigrant while $13 \%$ are Hispanic children of US-born parents. Also, Hispanic children of immigrants are more socioeconomically and socially disadvantaged than whites. Their mothers are more likely to have less than a high school education ( $41 \%$ versus $5 \%$ ), their average family income is lower, and they are more likely to be eligible to receive free or reduced-price school lunches (81\% versus $34 \%$ ). Additionally, $72 \%$ of Hispanic children of immigrants live in non-English speaking homes compared with $0 \%$ of white children. Hispanic children with US-born parents are also more disadvantaged than their white peers, but they are also more advantaged and more acculturated than Hispanic children of immigrants. For example, only 14\% have mothers with less than a high school education and only $5 \%$ live in non-English speaking households. 
Table 1: Weighted Descriptive Statistics for the Sample of ECLS-K: 2011 children and by ethnicity/parental nativity

\begin{tabular}{|c|c|c|c|c|}
\hline & $\begin{array}{l}\text { Full sample } \\
(\mathrm{N}=6,500)\end{array}$ & $\begin{array}{l}\text { White, US-born } \\
\text { parents } \\
(\mathrm{N}=4,310)\end{array}$ & $\begin{array}{l}\text { Hispanic children, } \\
\text { US-born parents } \\
(\mathrm{N}=810)\end{array}$ & $\begin{array}{l}\text { Hispanic children } \\
\text { of immigrants } \\
(\mathrm{N}=1,380)\end{array}$ \\
\hline & Mean/proportion & Mean/proportion & Mean/proportion & Mean/proportion \\
\hline \multicolumn{5}{|l|}{ Ethnicity and parental nativity } \\
\hline White, US-born parents & 0.67 & & & \\
\hline Hispanic, US-born parents & 0.13 & & & \\
\hline Hispanic children of immigrants & 0.20 & & & \\
\hline Age at kindergarten (in months) & 66.38 & 66.80 & 66.05 & 65.15 \\
\hline Birthweight (in ounces) & 114.86 & 116.34 & 111.49 & 111.99 \\
\hline \multicolumn{5}{|l|}{ Household structure } \\
\hline 2 bio./adoptive parents & 0.73 & 0.76 & 0.54 & 0.76 \\
\hline 1 bio./adoptive parent + stepparent & 0.07 & 0.08 & 0.11 & 0.04 \\
\hline Single parent & 0.18 & 0.15 & 0.32 & 0.18 \\
\hline Other guardian & 0.02 & 0.02 & 0.03 & 0.01 \\
\hline \multicolumn{5}{|l|}{ Maternal education } \\
\hline Less than high school & 0.13 & 0.05 & 0.14 & 0.41 \\
\hline High school or equivalent & 0.23 & 0.20 & 0.30 & 0.32 \\
\hline Some college or more & 0.64 & 0.76 & 0.56 & 0.27 \\
\hline Income category (range:1-18) & 8.39 & 9.25 & 7.34 & 6.17 \\
\hline Male & 0.52 & 0.52 & 0.51 & 0.52 \\
\hline Non-English speaking household & 0.15 & 0.00 & 0.05 & 0.72 \\
\hline Full-day kindergarten (ref: part-day) & 0.83 & 0.81 & 0.87 & 0.89 \\
\hline $\begin{array}{l}\text { Attended any center-based care/preschool/pre- } \\
\text { kindergarten }\end{array}$ & 0.55 & 0.58 & 0.50 & 0.48 \\
\hline Eligible for free or reduced-price lunch & 0.47 & 0.34 & 0.65 & 0.81 \\
\hline Kindergarten school year length (in months) & 9.39 & 9.36 & 9.41 & 9.47 \\
\hline $1^{\text {st }}$ grade school year length (in months) & 9.32 & 9.29 & 9.36 & 9.40 \\
\hline $2^{\text {nd }}$ grade school year length (in months) & 8.03 & 8.02 & 8.03 & 8.07 \\
\hline $\begin{array}{l}\text { Summer break between kindergarten and } 1^{\text {st }} \\
\text { grade (in months) }\end{array}$ & 2.60 & 2.63 & 2.56 & 2.50 \\
\hline $\begin{array}{l}\text { Summer break between } 1^{\text {st }} \text { and } 2^{\text {nd }} \text { grades (in } \\
\text { months) }\end{array}$ & 2.58 & 2.62 & 2.56 & 2.49 \\
\hline
\end{tabular}

Note: N's are rounded to the nearest 10 consistent with guidelines for utilizing the restricted-use ECLS-K:2011 data.

Table 2 shows children's average BMI and BMI z-score at the beginning of kindergarten (column 1) and the end of second grade (column 2). The average BMI of white children is significantly lower than that of Hispanic children of immigrants (by 0.65 BMI points) and Hispanic children of natives (by 0.57 BMI points). Results in column 2 indicate that children's average BMI is higher in second grade. Hispanic children of immigrants have a BMI score that is 1.03 points higher than whites and they 
are the heaviest group of children in the study. Hispanic children with US-born parents are also heavier (by 0.90 BMI points) than white peers. Results estimating group differences in weight using BMI z-scores, which are shown in the third and fourth column of results are similar to results in columns 1 and 2, but present a starker contrast in the weight of white and Hispanic children at kindergarten entry and at the end of second grade.

Table 2: Average BMI and group disparities in BMI at kindergarten entry (baseline) and the end of second grade

\begin{tabular}{|c|c|c|c|c|}
\hline & \multicolumn{2}{|c|}{ Mean BMI } & \multicolumn{2}{|c|}{ Mean BMI z-score } \\
\hline & Kindergarten entry & End of grade 2 & Kindergarten entry & End of grade 2 \\
\hline \multicolumn{5}{|l|}{ Children's ethnicity/parental nativity } \\
\hline White, US-born parents & $16.31^{\mathrm{ab}}$ & $17.38^{\mathrm{ab}}$ & $0.39^{\mathrm{ab}}$ & $0.25^{\mathrm{ab}}$ \\
\hline Hispanic, US-born parents & $16.88^{c}$ & $18.28^{c}$ & $0.65^{\mathrm{c}}$ & $0.52^{\mathrm{c}}$ \\
\hline Hispanic children of immigrants & $16.96^{\mathrm{c}}$ & $18.41^{\mathrm{c}}$ & $0.69^{\mathrm{C}}$ & $0.56^{\mathrm{C}}$ \\
\hline
\end{tabular}

Source: ECLS-K:2011.

Note: ${ }^{\mathrm{a} S i g n i f i c a n t l y ~ d i f f e r e n t ~ t h a n ~ H i s p a n i c ~ c h i l d r e n ~ w i t h ~ U S-b o r n ~ p a r e n t s . ~}{ }^{b}$ Significantly different than Hispanic children of immigrants. 'Significantly different than white children with US-born parents.

Estimates in Table 2 also indicate that Hispanic children gain more weight than white children with US-born parents between the beginning of kindergarten and the end of second grade. White children with US-born parents gain 1.07 BMI points. Hispanic children of immigrants and US-born parents gain 1.45 and 1.40 BMI points, respectively.

To pinpoint when these different groups of children gain weight, Table 3 presents estimates from multilevel growth curve models of monthly weight gain. Model 1 includes ethnicity/parental nativity, age, sex, and exposure to school years and summers. Estimates show that white children weigh significantly less than all Hispanic children at the beginning of kindergarten. Supplementary analyses indicated that Hispanic children with US-born and immigrant parents do not differ significantly in baseline weight upon kindergarten entry. Model 1 also indicates that on average, all children's monthly weight gain is significant and positive during each grade level and during summer break. Furthermore, consistent with prior research, average monthly weight gain in summer is higher (Von Hippel et al. 2007; Von Hippel and Workman 2016), but average monthly weight gain during the school year increases at each grade level.

Model 2 adds confounders, which leads the estimated difference in weight between white children and Hispanic children of immigrants at the beginning of kindergarten to be reduced by almost $60 \%$ from .60 to .23 BMI points. This difference is no longer statistically significant. The baseline kindergarten differences between these two groups 
in Model 1 is largely explained by language spoken at home and socioeconomic factors (maternal education, household income, and qualification for free or reduced-price school lunch). Hispanic children with US-born parents are still significantly heavier at baseline than whites in Model 2.

Table 3: $\quad$ Estimates from multilevel multivariate growth curve models predicting baseline and growth in weight

\begin{tabular}{|c|c|c|c|}
\hline & $\begin{array}{l}\text { M1 } \\
\text { B (SE) }\end{array}$ & $\begin{array}{l}\text { M2 } \\
\text { B (SE) }\end{array}$ & $\begin{array}{l}\text { M3 } \\
\text { B (SE) }\end{array}$ \\
\hline \multicolumn{4}{|c|}{ Ethnic/generational differences at beginning of kindergarten } \\
\hline \multicolumn{4}{|c|}{ Ethnicity/parental nativity (Ref: White, US-born parents) } \\
\hline Hispanic, US-born parents & $\begin{array}{l}0.46^{* * *} \\
(0.09)\end{array}$ & $\begin{array}{l}0.32 \text { *** } \\
(0.09)\end{array}$ & $\begin{array}{l}0.43^{* \star *} \\
(0.10)\end{array}$ \\
\hline Hispanic children of immigrants & $\begin{array}{l}0.60^{* * *} \\
(0.08)\end{array}$ & $\begin{array}{c}0.23 \\
(0.14)\end{array}$ & $\begin{array}{c}0.27 \\
(0.14)\end{array}$ \\
\hline \multicolumn{4}{|l|}{ Exposure to school years and summers } \\
\hline Kindergarten & $\begin{array}{l}0.01^{* *} \\
(0.00)\end{array}$ & $\begin{array}{l}0.01^{* * *} \\
(0.00)\end{array}$ & $\begin{array}{l}0.01 \text { * } \\
(0.00)\end{array}$ \\
\hline First grade & $\begin{array}{l}0.03^{* * *} \\
(0.00)\end{array}$ & $\begin{array}{l}0.03^{* \star *} \\
(0.00)\end{array}$ & $\begin{array}{l}0.02^{\star * *} \\
(0.01)\end{array}$ \\
\hline Second grade & $\begin{array}{l}0.05^{* * *} \\
(0.00)\end{array}$ & $\begin{array}{l}0.05^{* * *} \\
(0.00)\end{array}$ & $\begin{array}{l}0.05^{* \star *} \\
(0.00)\end{array}$ \\
\hline Summer between $\mathrm{K}-1$ & $\begin{array}{l}0.07^{* * *} \\
(0.01)\end{array}$ & $\begin{array}{l}0.07^{* * *} \\
(0.01)\end{array}$ & $\begin{array}{l}0.07 \\
(0.02)\end{array}$ \\
\hline Summer between $1-2$ & $\begin{array}{l}0.09 * * * \\
(0.01)\end{array}$ & $\begin{array}{l}0.09^{* * *} \\
(0.01)\end{array}$ & $\begin{array}{l}0.09 \\
(0.01)\end{array}$ \\
\hline \multicolumn{4}{|c|}{ Interaction between Ethnicity/parental nativity and exposure to school years and summers } \\
\hline Hispanic, US-born parents $\mathrm{x}$ kindergarten & & & $\begin{array}{c}0.01 \\
(0.01)\end{array}$ \\
\hline Hispanic, US-born parents $\mathrm{x}$ first grade & & & $\begin{array}{c}0.01 \\
(0.01)\end{array}$ \\
\hline Hispanic, US-born parents $\mathrm{x}$ second grade & & & $\begin{array}{c}0.01 \\
(0.01)\end{array}$ \\
\hline Hispanic, US-born parents $\mathrm{x}$ summer $\mathrm{K}-1$ & & & $\begin{array}{c}0.01 \\
(0.04)\end{array}$ \\
\hline Hispanic, US-born parents $x$ summer $1-2$ & & & $\begin{array}{c}0.01 \\
(0.03)\end{array}$ \\
\hline Hispanic children of immigrants $\mathrm{x}$ kindergarten & & & $\begin{array}{l}0.02^{* * *} \mathrm{a} \\
(0.01)\end{array}$ \\
\hline Hispanic children of immigrants $\mathrm{x}$ first grade & & & $\begin{array}{c}0.01 \\
(0.01)\end{array}$ \\
\hline Hispanic children of immigrants $x$ second grade & & & $\begin{array}{c}0.01 \\
(0.01)\end{array}$ \\
\hline Hispanic children of immigrants $\mathrm{x}$ summer $\mathrm{K}-1$ & & & $\begin{array}{c}-0.01 \\
(0.04)\end{array}$ \\
\hline Hispanic children of immigrants $\mathrm{x}$ summer $1-2$ & & & $\begin{array}{c}-0.00 \\
(0.03)\end{array}$ \\
\hline
\end{tabular}


Table 3: (Continued)

\begin{tabular}{|c|c|c|c|}
\hline & $\begin{array}{l}\text { M1 } \\
\text { B (SE) }\end{array}$ & $\begin{array}{l}\text { M2 } \\
\text { B (SE) }\end{array}$ & $\begin{array}{l}\text { M3 } \\
\text { B (SE) }\end{array}$ \\
\hline \multicolumn{4}{|l|}{ Confounders } \\
\hline \multirow[t]{2}{*}{ Age at kindergarten (in months) } & 0.01 * & 0.01 & 0.01 \\
\hline & $(0.01)$ & $(0.01)$ & $(0.01)$ \\
\hline \multirow[t]{2}{*}{ Male } & $0.19^{* *}$ & 0.16 ** & 0.16 ** \\
\hline & $(0.06)$ & $(0.06)$ & $(0.06)$ \\
\hline \multirow[t]{2}{*}{ Birthweight (in ounces) } & & $0.01 * \star *$ & $0.01^{* * *}$ \\
\hline & & $(0.00)$ & $(0.00)$ \\
\hline \multicolumn{4}{|l|}{ Household structure (Ref: 2 parents) } \\
\hline \multirow[t]{2}{*}{ Single parent household } & & $0.21 * *$ & $0.21^{* *}$ \\
\hline & & $(0.08)$ & $(0.08)$ \\
\hline \multirow[t]{2}{*}{ Stepparent household } & & 0.09 & 0.09 \\
\hline & & $(0.14)$ & $(0.14)$ \\
\hline \multirow[t]{2}{*}{ Other } & & $0.65 *$ & $0.65 *$ \\
\hline & & $(0.28)$ & $(0.28)$ \\
\hline \multicolumn{4}{|c|}{ Maternal education (Ref: High school or equivalent) } \\
\hline \multirow[t]{2}{*}{ Less than high school } & & -0.07 & -0.07 \\
\hline & & $(0.11)$ & $(0.11)$ \\
\hline \multirow[t]{2}{*}{ Some college or more } & & -0.04 & -0.04 \\
\hline & & $(0.09)$ & $(0.09)$ \\
\hline \multirow[t]{2}{*}{ Income category } & & -0.02 & -0.02 \\
\hline & & $(0.01)$ & $(0.01)$ \\
\hline \multirow[t]{2}{*}{ Non-English speaking household } & & 0.30 * & $0.30 *$ \\
\hline & & $(0.15)$ & $(0.15)$ \\
\hline \multirow[t]{2}{*}{ Full day kindergarten (ref: part-day) } & & $0.21 * *$ & 0.21 ** \\
\hline & & $(0.08)$ & $(0.08)$ \\
\hline \multirow[t]{2}{*}{ Attended any center-based care/preschool/pre-k } & & -0.01 & -0.01 \\
\hline & & $(0.06)$ & $(0.06)$ \\
\hline \multirow[t]{2}{*}{ Eligible for free or reduced-price lunch } & & $0.26 * * *$ & $0.26 * * *$ \\
\hline & & $(0.08)$ & $(0.08)$ \\
\hline \multirow[t]{2}{*}{ Intercept } & $15.27^{* * *}$ & 14.30 & 14.27 \\
\hline & $(0.53)$ & $(0.50)$ & $(0.50)$ \\
\hline
\end{tabular}

Source: ECLS-K:2011 data: 39,000 weight records from 6,500 children nested in 850 elementary schools. Ns are rounded to the nearest 10 consistent with guidelines for utilizing the restricted-use ECLS-K:2011 data.

Notes: ${ }^{*} p \leq .05^{\star *} p \leq .01^{* \star *} p \leq .001{ }^{\mathrm{a}}$ In supplementary models, when Hispanic children with US-born parents are the reference category, Hispanic children of immigrants are significantly different than Hispanic children of natives $(p<0.05)$.

In Model 3, we test whether Hispanic children of immigrants gain significantly more weight than white and Hispanic peers with US-born parents during kindergarten, first grade, and second grade by adding interaction terms to Model 2. Hispanic children of immigrants gain significantly more weight during kindergarten than white children, but they did not differ significantly from whites at kindergarten entry or in monthly weight gain during first or second grade. As designated by superscript 'a' in Table 3, Hispanic children of immigrants also have higher monthly weight gain during kindergarten than Hispanic children with US-born parents. In contrast to Hispanic 
children of immigrants, Hispanic children of natives weigh significantly more than white children when they start kindergarten entry but did not differ from whites in monthly weight gain during the school years or summer breaks. Supplementary analysis indicated that results from Model 3 were robust to controlling for school-level socioeconomic status, racial/ethnic composition, and the proportion of kindergarten English language learners in the school (results available upon request).

Table 4 presents our final study estimates. Column 1 shows adjusted estimates of how Hispanic children of immigrants' baseline weight and weight gain during school years and summer breaks contribute to predicted group differences in their weight and the weight of white peers by the end of second grade. Estimates were derived using results from Model 3 in Table 3 and take into account the cumulative lengths of time children, on average, spend at school during the school years and on summer breaks.

Table 4: The contribution of school and summer weight gain to group differences in weight by the end of second grade

\begin{tabular}{|c|c|c|}
\hline White children versus: & Hispanic children of immigrants & Hispanic, US-born parents \\
\hline \multirow[t]{2}{*}{ Total difference } & $0.700^{\star \star \star}$ & 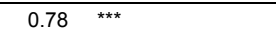 \\
\hline & $(0.16)$ & $(0.14)$ \\
\hline \multicolumn{3}{|l|}{ Difference due to differences in } \\
\hline \multirow[t]{2}{*}{ Weight at baseline } & 0.27 & $0.42^{* \star *}$ \\
\hline & $(0.14)$ & $(0.15)$ \\
\hline \multirow[t]{2}{*}{ School year weight gain } & $0.45 *$ & 0.30 \\
\hline & $(0.17)$ & $(0.10)$ \\
\hline \multirow[t]{2}{*}{ Kindergarten weight gain } & $0.20^{\star * *}$ & 0.05 \\
\hline & $(0.06)$ & $(0.06)$ \\
\hline \multirow{2}{*}{ First grade weight gain } & 0.13 & 0.12 \\
\hline & $(0.11)$ & $(0.10)$ \\
\hline \multirow[t]{2}{*}{ Second grade weight gain } & 0.12 & 0.13 \\
\hline & $(0.10)$ & $(0.12)$ \\
\hline \multirow[t]{2}{*}{ Summer weight gain } & -0.02 & 0.06 \\
\hline & $(0.15)$ & $(0.13)$ \\
\hline \multirow[t]{2}{*}{ Between $\mathrm{K}$ and first grade } & -0.01 & 0.04 \\
\hline & $(0.10)$ & $(0.10)$ \\
\hline \multirow[t]{2}{*}{ Between first and second grade } & -0.10 & 0.02 \\
\hline & $(0.08)$ & $(0.09)$ \\
\hline
\end{tabular}

Source: ECLS-K:2011 data: 39,000 weight records from 6,500 children nested in 850 elementary schools. N's are rounded to the nearest 10 consistent with guidelines for utilizing the restricted-use ECLS-K:2011 data. Notes: ${ }^{*} p \leq .05^{* \star} p \leq .01{ }^{\star \star \star} p \leq .001$

Column 1 indicates that the significant difference in the weight of whites and Hispanic children of immigrants is significantly attributable to the sum of all school year weight gains. This contributes to $64.3 \%$ of the difference $(0.45 / 0.70)$. Kindergarten weight gain alone makes a significant contribution to the weight difference of Hispanic 
children of immigrants and whites. Baseline weight at kindergarten entry and differences in summer weight gains do not contribute significantly to group differences.

Result in column 2 compare Hispanic and white children with US-born parents. There is a significant .78 between-group difference in BMI by the end of second grade, but it is not due to school year weight gains. Instead, the significantly higher baseline BMI of Hispanic children with US-born parents contributes to more than half $(54.8 \%)$ of the total difference.

\section{Discussion}

Informed by new assimilation theory (Alba and Nee 2003), we investigated whether elementary school is a formal US social institution that inadvertently facilitates greater school year weight gain among Hispanic children of immigrants relative to white and Hispanic children with US-born parents. We also investigated whether the accumulation of school year weight gain during kindergarten, first grade, and second grade contributed to Hispanic children of immigrants' propensity to be heavier than white peers with US-born parents, and whether this phenomenon was unique to children of immigrants or evident among all Hispanic children.

We found that the monthly weight gain of Hispanic children of immigrants is higher than white and Hispanic children with US-born parents during the kindergarten school year. In addition, the accumulation of all school year weight gains in kindergarten, first grade, and second grade account for $64 \%$ of the BMI difference between whites and Hispanic children of immigrants at the end of second grade, with kindergarten weight gain making the largest contribution to this disparity. In contrast, summer weight gains and baseline weight at kindergarten entry did not contribute significantly to differences between these two groups of children. Study findings are largely consistent with research expectations and suggest that elementary school entry is a vulnerable period for Hispanic children of immigrants' weight gain. The kindergarten school year, which largely aligns with the average age of the adiposity rebound, is an especially important intervention point for reducing weight gain and obesity among Hispanic children of immigrants.

These findings should not be interpreted to mean that elementary schools deliberately promote weight gain among Hispanic children of immigrants or children more generally. On the contrary, elementary schools are instrumental in childhood obesity prevention efforts (Story, Kaphingst, and French 2006; Weschler et al. 2000).

Yet the efforts of schools to combat obesity does not mean that Hispanic children of immigrants are not more vulnerable to weight gain during the school year than peers with US-born parents. Indeed, study findings align with new assimilation theory, which 
argues that mainstream social institutions such as school have formal and informal structures that foster assimilation among immigrants and their families (Alba and Nee 2003). Prior research suggests that these institutional forces lead Hispanic children of immigrants to face stress due to pressure to assimilate (Alba and Nee 2003; Pong and Hao 2007; Rumbaut 1994); to eat more Americanized food at school due to school constraints on meals served (Poppendick 2010; Weaver-Hightower 2011) and peer norms regarding eating (Salazar 2007); and to overeat Americanized food when their identity may be questioned (Gundelman, Cheryan, and Monin 2011).

In supplementary analyses, study findings were even stronger in analyses constrained to Hispanic and white children who did not attend pre-kindergarten or preschool, meaning that they were entirely new to the US school system upon kindergarten entry. This further supports new assimilation theory and further suggests that Hispanic children of immigrants are vulnerable to weight gain when they enter the social institution of elementary school. Nonetheless, we must be cautious about whether stress and dietary behaviors are the mechanisms that explain this phenomenon because data limitations preclude us from formally testing theorized mechanisms.

Our overall study goal was to investigate whether Hispanic children of immigrants were vulnerable to weight gain upon entry into a new US social institution. Study findings for Hispanic children with US-born parents help to clarify the role that social institutions have in Hispanic children's lives and show the importance of de-coupling Hispanic children with immigrant and US-born parents. Hispanic children with USborn parents did not gain significantly more weight per month during the school year than white children with US-born parents, and school year weight gains did not significantly contribute to disparities in weight between these two groups. This further suggests that our findings about school year weight gain for Hispanic children of immigrants may be due to the way that entering the social institution of school leads to general assimilation and dietary assimilation.

Findings for Hispanic children with US-born parents also build on and clarify previous research that suggested that all Hispanic children are vulnerable to school year weight gain (Von Hippel and Workman 2016). Our study shows that this is a phenomenon unique to Hispanic children of immigrants and not all Hispanic children.

Findings from analyses that de-couple Hispanic children with US-born and immigrant parents also allow us to speculate about how family, the primary social institution in all children's lives, may contribute to weight gain prior to school entry. Our results suggested that for Hispanic children of immigrants, family disadvantage explained why they were significantly heavier than whites upon kindergarten entry. These factors (at least as modeled in our study) did not explain why Hispanic children with US-born parents weigh more than white peers upon elementary school entry. Parental feeding practices could at least in part explain this difference. US-born 
Hispanic mothers are more likely than white mothers to introduce solid foods early, use restrictive feeding practices, and have children who consume more sugar-sweetened beverages and fast food (Taversas et al. 2010).

Our results open up several lines of investigation for future research. First, although prior theory and research suggest mechanisms for study findings, future research should investigate whether stress, dietary changes, or other individual-level and school-level mechanisms explain Hispanic children of immigrants' vulnerability to weight gain during the kindergarten school year and why school year weight gains accumulate to make them significantly heavier than white children with US-born parents over time. Future research is also needed to better understand why patterns of weight gain are different for Hispanic children with foreign-born and US-born parents. Finally, although we are interested in schools as formal US social institutions in line with new assimilation theory, we recognize that segmented assimilation theory points to diverse outcomes and variegated process of adaptation and assimilation among children of immigrants that is dependent on several aspects of their background including their race, national origin, locational context, and socioeconomic status (Portes and Zhou 1993). We did not have the statistical power to estimate three-way interactions, but future research should investigate whether key characteristics of Hispanic children of immigrants and their schools, such as family socioeconomic resources or school racial composition, modify their vulnerability to school year weight gain.

Study findings and our interpretation of them, have limitations. Our analyses examines group differences in weight gain through the end of second grade, not later elementary, junior high, and high school years when students are older and have more independence over behaviors that influence weight. We also did not disaggregate between different types of Hispanic immigrants or other immigrant groups due to issues of statistical power. The Americanization of children of immigrants depends in part on parents' country of origin because the "bleed" that US customs, norms, and products have to other countries varies widely (Rumbaut 1997). Thus, children of immigrants who enter the United States less exposed to the US and Americanized eating than Hispanic children of immigrants may be at even greater risk when they first start school. We also cannot distinguish fine-grain differences in acculturation that others have demonstrated to be evident among children of immigrants (Nieri et al. 2011).

Despite limitations, study results show that elementary school exposure appears to facilitate weight gain more for Hispanic children of immigrants than their US-born peers. In addition, findings show how new assimilation theory can be used to think about how foundational social institutions in the United States may foster health assimilation. Future research should continue to explore how US social institutions promote and foster health assimilation in both negative and positive ways. 


\section{References}

Akresh, I.R. (2007). Dietary assimilation and health among Hispanic immigrants to the United States. Journal of Health and Social Behavior 48(4): 404-417. doi: $10.1177 / 002214650704800405$.

Alba, R. and Nee, V. (2003). Remaking the American mainstream: Assimilation and contemporary immigration. Cambridge: Harvard University Press. doi:10.4159/ 9780674020115 .

Antecol, H. and Bedard, K. (2006). Unhealthy assimilation: Why do immigrants converge to American health status levels? Demography 43(2): 337-360. doi:10.1353/dem.2006.0011.

Apple, M.W. and King, N.R. (1977). What do schools teach? Curriculum Inquiry 6(4): 341-358. doi:10.1080/03626784.1977.11075550.

Balistreri, K.S. and Van Hook, J. (2009). Socioeconomic status and body mass index among Hispanic children of immigrants and children of natives. American Journal of Public Health 99(12): 2238-2246. doi:10.2105/AJPH.2007.116103.

Berkey, C. and Colditz, G. (2007). Adiposity in adolescents: Change in actual BMI works better than change in BMI z-score for longitudinal studies. Annals of Epidemiology 17(1): 44-50. doi:10.1016/j.annepidem.2006.07.014.

Berry, J.W. (2006). Acculturative stress. In: Wong, P.T. and Wong, L.C. (eds.). Handbook of multicultural persoectives on stress and coping. New York: Springer: 287-298.

Bordieu, P. (1977). Cultural reproduction and the social reproduction. In: Halsey, J.K. and Halsey, A.H. (eds.). Power and ideology in education. New York: Oxford University Press: 487-511.

Capps, R., Fix, M., Murray, J., Ost, J., and Passel, J. (2005). The new demography of America's schools: Immigration and the No Child Left Behind Act. Washington, D.C.: Migration Policy Institute.

Cole, T.J. (2004). Children grow and horses race: Is the adiposity rebound a critical period for later obesity? BMC Pediatrics 4(6): 1-7. doi:10.1186/1471-2431-4-6.

Cole, T.J., Faith, M.S., Pietrobelli, A., and Heo, M. (2005). What is the best measurement of adiposity change in growing children: BMI, BMI \%, BMI zscore or BMI percentile? European Journal of Clinical Nutrition 59(2): 419425. doi:10.1038/sj.ejen.1602090. 
Dietz, W. (1998). Health consequences of obesity in youth: Childhood predictors of adult disease. Pediatrics 101(3): 518-525.

Dondero, M. and Van Hook, J. (2006). Generational status, neighborhood context, and mother-child resemblance in dietary quality in Mexican-origin families. Social Science and Medicine 150: 212-220. doi:10.1016/j.socscimed.2015.12.023.

Dondero, M., Van Hook, J., Frisco, M.L., and Martin, M.A. (2018). Dietary acculturation and dietary quality among Mexican children of immigrants: The role of food settings. Journal of Health and Social Behavior 59(4): 464-488. doi:10.1177/0022146518809995.

Drapeau, V., Therrien, F., Richard, D., and Tremblay, A. (2003). Is visceral obesity a physiological adaptation to stress? Panminerva Medica 45(3): 189-196.

Eccles, J. (1999). The development of children ages 6 to 14. The Future of Children 9(2): 30-44.

Frisco, M.L., Quiros, S., and Van Hook, J. (2016). One size may not fit all: How obesity among Mexican-origin youth varies by generation, gender, and age. Demography 53(6): 2031-2043. doi:10.1007/s13524-016-0525-3.

Fry, R. and Passel, J. (2009). Latino children: A majority are US-born offspring of immigrants. Washington, D.C.: Pew Research Center.

Gordon-Larsen, P., Harris, K., Ward, D.S., and Popkin, B.M. (2003). Acculturation and overweight-related behaviors among Hispanic immigrants to the US: The National Longitudinal Study of Adolescent Health. Social Science and Medicine 57(11): 2023-2034.

Gordon, M.M. (1964). Assimilation in American life. New York: Oxford University Press.

Gundelman, M.D., Cheryan, S., and Monin, B. (2011). Fitting in but getting fat: Identity threat and dietary choices among US immigrant groups. Psychological Sciences 22(7): 959-967. doi:10.1177/0956797611411585.

Hamilton, E., Cardoso, J.B., Hummer, R.A., and Padilla, Y.C. (2011). Assimilation and emerging health disparities among new generations of US children. Demographic Research 25(25): 783-818. doi:10.4054/DemRes.2011.25.25.

Johnson, D.R. and Young, R. (2011). Toward best practices in analyzing datasets with missing data: Comparisons and recommendations. Journal of Marriage and Family 73(5): 926-945. doi:10.1111/j.1741-3737.2011.00861.x. 
Kimbro, R.T. and Denney, J.T. (2013). Neighborhood context and racial/ethnic differences in young children's obesity: Structural barriers to interventions. Social Science and Medicine 95: 97-105. doi:10.1016/j.socscimed.2012.09.032.

Laureau, A. (2011). Unequal childhoods: Class, race, and family life. Berkeley: University of California Press.

Magnuson, K., Lahaie, C., and Waldfolgel, J. (2006). Preschool and school readiness of children of immigrants. Social Science Quarterly 87(5): 1241-1262.

Masters, R., Powers, D., and Link, B.G. (2013). Obesity and US mortality risk over the adult life course. American Journal of Epidemiology 177(5): 431-442. doi:10.1093/aje/kws325.

McArthur, L.H., Anguiano, R.P., and Nocetti, D. (2001). Maintenance and change in the diet of Hispanic immigrants in eastern North Carolina. Family and Consumer Sciences Research Journal 29(4): 309-335. doi:10.1177/ 1077727 X01294002.

National Center for Education Statistics (2018). Kindergarten class of 2010-11 study information [electronic resource]. Washington, D.C.: National Center for Education Statistics. https://nces.ed.gov/ecls/kindergarten2011.asp.

Nieri, T., Lee, C., Kulis, S., and Marsiglia, F. (2011). Acculturation among Mexicanheritage preadolescents: A latent class analysis. Social Science Research 40(4): 1236-1248. doi:10.1016/j.ssresearch.2011.02.005.

Ogden, C.L., Fryar, C.D., Hales, C.M., Carroll, M.D., Aoki, Y., and Freedman, D.S. (2018). Differences in obesity prevalence by demographics and urbanization in US children and adolescents, 2013-2016. JAMA 319(23): 2410-2418. doi:10.1001/jama.2018.5158.

Pong, S.-L. and Hao, L. (2007). Neighborhood and school factors in the school performance of immigrants' children. International Migration Review 41(1): 206-241. doi:10.1111/J.1747-7379.2007.00062.x.

Popkin, B.M. and Udry, J.R. (1998). Adolescent obesity increases significantly in second and third generation United States immigrants: The National Longitudinal Study of Adolescent Health. Journal of Nutrition 128(4): 701-706. doi:10.1093/jn/128.4.701.

Poppendick, J. (2010). Free for all: Fixing school food in America. Oakland: University of California Press. 
Portes, A. and Zhou, M. (1993). The new second generation: Segmented assimilation and its variants. The Annals of the American Academy of Political and Social Science 530: 74-96.

Preston, S., Vierboom, Y.C., and Stokes, A. (2018). The role of obesity in exceptionally slow US mortality improvement. PNAS: Proceedings of the National Academy of Sciences 115(5): 957-961. doi:10.1073/pnas.1716802115.

Rosenbloom, S.R. and Way, N. (2004). Experiences of discrimination among African American, Asian American, and Latino adolescents in an urban high school. Youth and Society 35(4): 420-451. doi:10.1177/0044118X03261479.

Rubin, R. (1987). Multiple imputation for nonresponse in surveys. New York: Wiley. doi:10.1002/9780470316696.

Rumbaut, R.G. (1994). The crucible within: Ethnic identity, self-esteem, and segmented assimilation among children of immigrants. International Migration Review 28(4): 748-794.

Rumbaut, R.G. (1997). Assimilation and its discontents: Between rhetoric and reality. International Migration Review 31(4): 923-960. doi:10.1177/ 019791839703100406.

Rumbaut, R.G. (2005). Children of immigrants and their achievement: The roles of family, acculturation, social class, gender, ethnicity and school context. In: Taylor, R.D. (ed.). Addressing the achievement gap: Theory informing practice. Scottsdale: Information Age Publishing.

Salazar, M.L. (2007). Public schools, private foods: Mexicano memories of culture and conflict in American school cafeterias. Food and Foodways 15(3-4): 153-181. doi:10.1080/07409710701620078.

Story, M., Kaphingst, K.M., and French, S. (2006). The role of schools in obesity prevention. The Future of Children 16(1): 109-142.

Suárez-Orozco, C. and Suárez-Orozco, M.M. (2009). Children of immigration. Boston: Harvard University Press.

Sussner, K.M., Lindsay, A.C., and Peterson, K.E. (2009). The influence of maternal acculturation on child body mass index at age 24 months. Journal of the American Dietetic Association 109(2): 218-225. doi:10.1016/j.jada.2008.10.056.

Taversas, E., Gillman, M., Klienman, K., Rich-Edwards, J., and Rifas-Shirma, S.L. (2010). Racial/ethnic differences in early-life risk factors for childhood obesity. Pediatrics 125(4): 686-695. doi:10.1542/peds.2009-2100. 
Turney, K. and Kao, G. (2009). Pre-kindergarten child care and behavioral outcomes among children of immigrants. Early Childhood Research Quarterly 24(4): 432444. doi:10.1016/j.ecresq.2009.07.007.

USDA (2017). National school lunch, special milk, and school breakfast programs, national average payments/maximum reimbursement rates. Federal Register 82(144): 35175-35178.

Van Hook, J., Baker, E., and Altman, C. (2009). Does it begin at school or home? The institutional origins of overweight among young children of immigrants. In: Grigorenki, E.L. and Takanishi, R. (eds.). Immigration, diversity, and education. New York: Routledge/Taylor and Francis: 205-224.

Van Hook, J., Baker, E., Altman, C., and Frisco, M.L. (2012). Canaries in a coalmine: Immigration and overweight among Mexican-origin children in the US and Mexico. Social Science and Medicine 74(2): 125-134. doi:10.1016/j.socscimed. 2011.10.007.

Van Hook, J., Quiros, S., Frisco, M.L., and Firku, E. (2016). It is hard to swim upstream: Dietary acculturation among Mexican-origin children. Population Research and Policy Review 35(2): 177-196. doi:10.1007/s11113-015-9381-x.

Van Hook, J. and Baker, E. (2010). Big boys and little girls: Gender, acculturation, and weight among young children of immigrants. Journal of Health and Social Behavior 51(2): 200-214. doi:10.1177/0022146510372347.

Von Hippel, P.T., Powell, B., Downey, D.B., and Rowland, N.J. (2007). Changes in children's body mass index during the school year and during summer vacation. American Journal of Public Health 97(3): 1-7. doi:10.2105/AJPH.2005.080754.

Von Hippel, P.T. and Workman, J. (2016). From kindergarten through second grade, US children's obesity prevalence grows only during summer vacations. Obesity 24(11): 2296-2300. doi:10.1002/oby.21613.

Weaver-Hightower, M.B. (2011). Why education researchers should take school food seriously. Education Researcher 40(1): 15-21. doi:10.3102/ 0013189X10397043.

Weschler, H., Deveraux, R.S., Davis, M., and Collins, J. (2000). Using the school environment to promote physical activity and healthy eating. Preventative Medicine 21(2): S121-S137. doi:10.1006/pmed.2000.0649. 
Young, R. and Johnson, D. (2018). Imputing the missing Y's: Implications for survey producers and survey users [electronic resource]. Oakbrook Terrace: American Association for Public Opinion Research. https://www.researchgate.net/ publication/266357732_Imputing_the_Missing_Y's_Implications_for_Survey_P roducers_and_Survey_Users. 
Frisco, Baumgartner \& Van Hook: The weight of school entry 